\title{
Postural laterality in torticollis and torsion dystonia
}

\author{
L STEJSKAL, Z TOMÁNEK \\ From the Clinic of Neurological Surgery of the Charles University and from the Department of \\ Otorhinolaryngology, Prague, Czechoslovakia
}

SUMMARY Tests of postural rotational laterality were carried out in 63 patients suffering from torticollis (53) or torsion dystonia with torticollis (10) and in 33 normal subjects. There was a correlation between the predominant direction of postural functions and the direction of the rotatory component of torticollis. Torticollis and torsion dystonia may be due to the release of a postural rotational laterality in pre-disposed subjects and not to a presumed asymmetric lesion of the brain-stem.

Stereotyped movements are a striking feature in axial dyskinesias (torsion dystonia and torticollis): the involuntary movement of the head, trunk and limbs is repeated in the same plane and in the same direction ("richtungsbestimmte Bewegungen"1). Another characteristic sign of the axial dyskinesia is the rotational asymmetry of the non-volitional movement: a more or less marked turning movement to the right or to the left is present in every patient, whereas flexion, extension or tilting of the head (and trunk) may not always be present. ${ }^{2}$

Post-mortem findings contrast with the stereotyped and asymmetric clinical findings. A decreased number of ganglia cells in cortex, cerebellum and basal ganglia (mainly in caudate nucleus and putamen) in both halves of the brain has been reported by many authors. ${ }^{3-9}$ Only Hassler and Dieckmann ${ }^{10}$ described unilateral cell loss in the left thalamus in a case of predominantly left-sided torsion dystonia. Other authors were unable to find any pathomorphological changes which could be correlated with torticollis and torsion dystonia. ${ }^{11-13}$ Histological sections from earlier reports were re-examined by Zeman and Dyken ${ }^{14}$ (from cases of torsion dystonia ${ }^{15}$ ) and by Tarlov ${ }^{13}$ (from cases of torticollis ${ }^{16-18}$ ) with the conclusion that no pathological changes could be found. In some cases described as examples of torticollis or torsion dystonia, the clinical condition originally was reported under other titles, ${ }^{19-21}$ then later quoted. ${ }^{22}$

What is the reason for the stereotyped rotational postures in patients suffering from torticollis and

Address for reprint requests: L Stejskal, MD, Neurosurgical Clinic, Prague 6, Střešovice 1200, Czechoslovakia.

Received 11 December 1980, revision received 21 July 1981 Accepted 8 August 1981 torsion dystonia? It is possible that a pre-existing rotational laterality is unmasked by the disease. Accordingly, postural and related motor and sensory functions were tested in a group of patients with torticollis and in a control group of normal subjects.

\section{Material and methods}

Sixty-three adult patients ( 33 men and 30 women) aged between 17 and 57 years at the time of the onset of the illness (mean age $34 \cdot 3$ years, SD $9 \cdot 58$ years), 53 of whom had isolated torticollis and 10 of whom had torticollis with dystonic movements of the limbs, were divided into two groups according to the direction of rotation of the head: $L$, that is left-rotated $(n=33)$ and $R$, that is right-rotated $(n=30)$. The direction of rotation of the head was established by integrated fine-wire electromyography of the neck muscles (the sternocleidomastoid, the scalenus, the splenius, the levator scapulae, the trapezius and the cervical semispinal muscles of both sides), and by photographs taken from four sides of patients in the standing position. The objection that the laterality of motor functions could be the result of (and not the reason for) the asymmetric involuntary posture was irrelevant because not only patients with marked dyskinesia were tested $(54 \%)$, but also those who had partially or completely recovered $(46 \%)$.

The laterality of the hand was tested by 16 manoeuvres. The laterality of the auditory system was examined by means of a dichotic listening test, ${ }^{23}$ in which 20 pairs of three-digit figures were synchronously delivered to both ears. For vestibular functions, the duration, the total amplitude, and the maximum velocity of the low phase of the caloric nystagmus elicited by the technique of Fitzgerald and Hallpike ${ }^{24}$ were registered by means of electronystagmography in total darkness, without a fixation point. Only nystagmus elicited by cold water $\left(20^{\circ} \mathrm{C}\right)$ was of sufficient intensity and suitable for statistical evaluation in all cases (the instability of the head due to dyskinetic movements caused artificial dysrhythmia and 
inhibition of rotational and $44^{\circ} \mathrm{C}$ nystagmus). The laterality of turning of the body was examined by 16 tests without the subject realising the aim of the tests (the direction of turning back in the examination of walking, the direction of quick turning during the examination of stability in the standing and in the squatting position, all tests being repeated with eyes open and closed). The same vestibular functions and tests of turning of the body were examined in the control group of 33 adult normals (group N) aged between 17 to 45 years (mean age $29 \cdot 2$ years, SD 6.18 years). The mean values in each group were ascertained and the differences between groups $\mathrm{L}$, $\mathrm{R}$ and $\mathrm{N}$ were statistically evaluated by Student's $t$ test.

To confirm the constancy of the individual vestibular laterality, directional preponderance and "canal paresis" pattern of the caloric nystagmus $\left(20^{\circ} \mathrm{C}\right.$ and $\left.44^{\circ} \mathrm{C}\right)$ were re-evaluated in 20 patients $(10 \mathrm{~L}$ and $10 \mathrm{R})$ tested two years earlier. All had either completely recovered or exhibited a considerable reduction of dyskinesia; their EMG however retained asymmetric activity at rest (fig 1).

\section{Results}

No difference in hand laterality was observed between the torticollis groups $\mathrm{L}$ and $\mathrm{R}$ and the normal subjects. There was no correlation between the predominant hand and the direction of torticollis. Ninety-two per cent of the subjects were righthanded.

No difference in ear laterality was observed between the torticollis groups $\mathrm{L}$ and $\mathrm{R}$ and the normal subjects. There was no correlation between the predominant ear and the direction of torticollis. The right ear was dominant in $73 \%$ of subjects.

Nystagmus elicited by cold water was exaggerated bilaterally in groups $\mathrm{L}$ and $\mathrm{R}$, exceeding mean values obtained in normals by $2 \%-17 \%$ for the duration, by $15 \%-70 \%$ for the total amplitude, and by $12 \%-62 \%$ for the maximum velocity of the slow phase (table 1). Nystagmus elicited by cold water in the torticollis groups $\mathbf{L}$ and $\mathbf{R}$ was asymmetric. Nystagmus with the slow phase in the direction of the rotation of the head was of longer duration, of greater amplitude and of higher velocity (figs 2, 3). There was a correlation between the greater nystagmus and the direction of torticollis (table 1). The
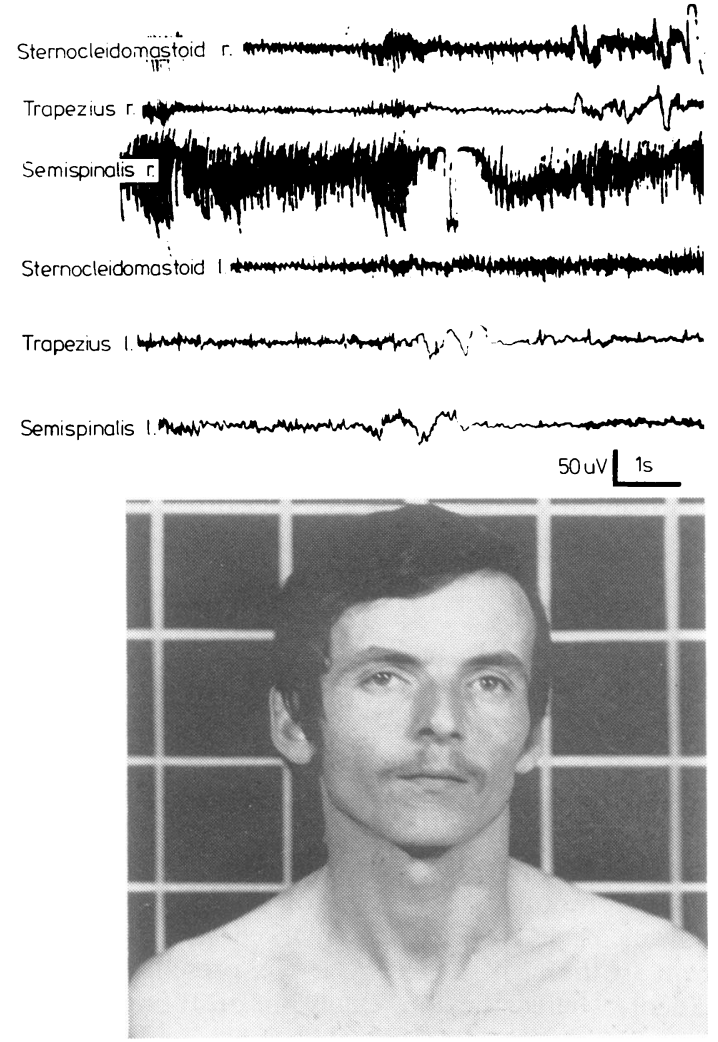

Fig 1 EMG pattern in a man previously suffering from torticollis with rotation of the head to the right. The dyskinesia disappeared, the prime-mover (m. semispinalis cervicis of the right side) is, however, still hyperactive at rest.

direction of nystagmus asymmetry was the same in all 20 patients re-examined, the slow phase of the preponderating nystagmus being consonant with the direction of torticollis in 17 of 20 patients.

In walking, standing and squatting tests, there was a greater tendency to turn to the left side in the torticollis group $\mathrm{L}$ and in normal subjects. There was a correlation between the preferred "turning

Table 1 Mean values of nystagmus evoked by cold water $\left(20^{\circ} \mathrm{C}\right)$ in patients with torticollis to the left $(L, n=33)$ and to the right $(R, n=30)$ and in the control group $(N, n=33)$. Significance of differences

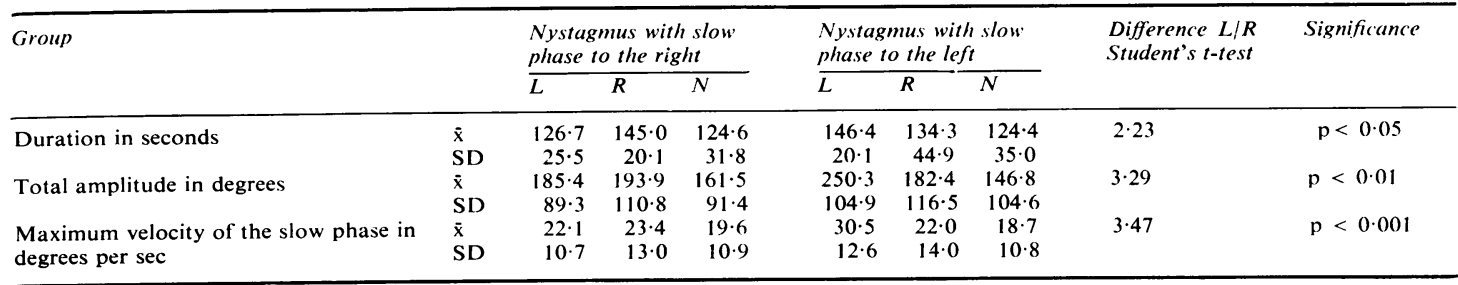



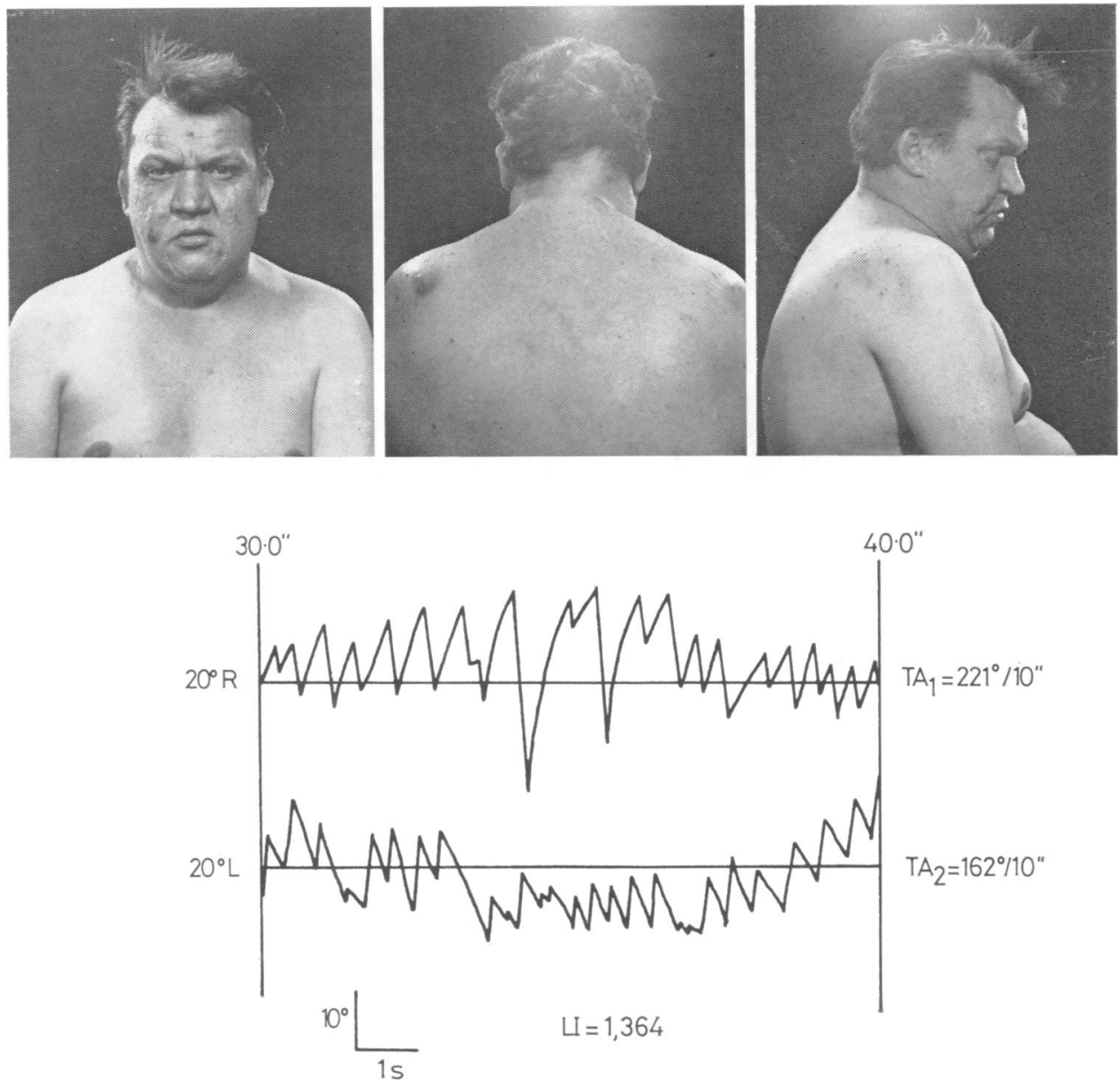

Fig 2 Nystagmus pattern in a man suffering from torticollis with rotation of the head to the right. The total amplitude of the caloric nystagmus with slow phases to the right $\left(T A_{1}\right)$ predominates.

direction" and the direction of torticollis $(\mathrm{p}<0.001$, table 2).

Table 2 Rates of turns about in walking, standing and squatting positions

\begin{tabular}{llll}
\hline Group & $L$ & $N$ & $R$ \\
\hline Turns to the left & $89 \%$ & $71 \%$ & $46 \%$ \\
Turns to the right & $11 \%$ & $29 \%$ & $54 \%$ \\
\cline { 2 - 4 } Total sum of tests & $100 \%$ & $100 \%$ & $100 \%$ \\
\hline
\end{tabular}

\section{Discussion}

Maier ${ }^{25}$ described experiments in which albino rats were faced with an insoluble problem in a Lashley jumping apparatus. They were forced to jump and whatever solution they chose, they were "punished" in half of their jumps. Such rats tended to develop "behaviour-fixations"; after some time, they commonly jumped, for example, always to the right, regardless of the stimulus situation, even if the food was visible on the left-hand side. Maier states: "It appears that the fixated group develops some kind of adjustment to the test situation and is therefore able to prevent emotional tensions". The onset of an audiogenic epileptic seizure in rats is manifested by the tonic deviation of the head and tail to one side followed by the running in the circle in the same direction.

In some dogs placed into a standard empty room another stressful condition evokes an epileptic 

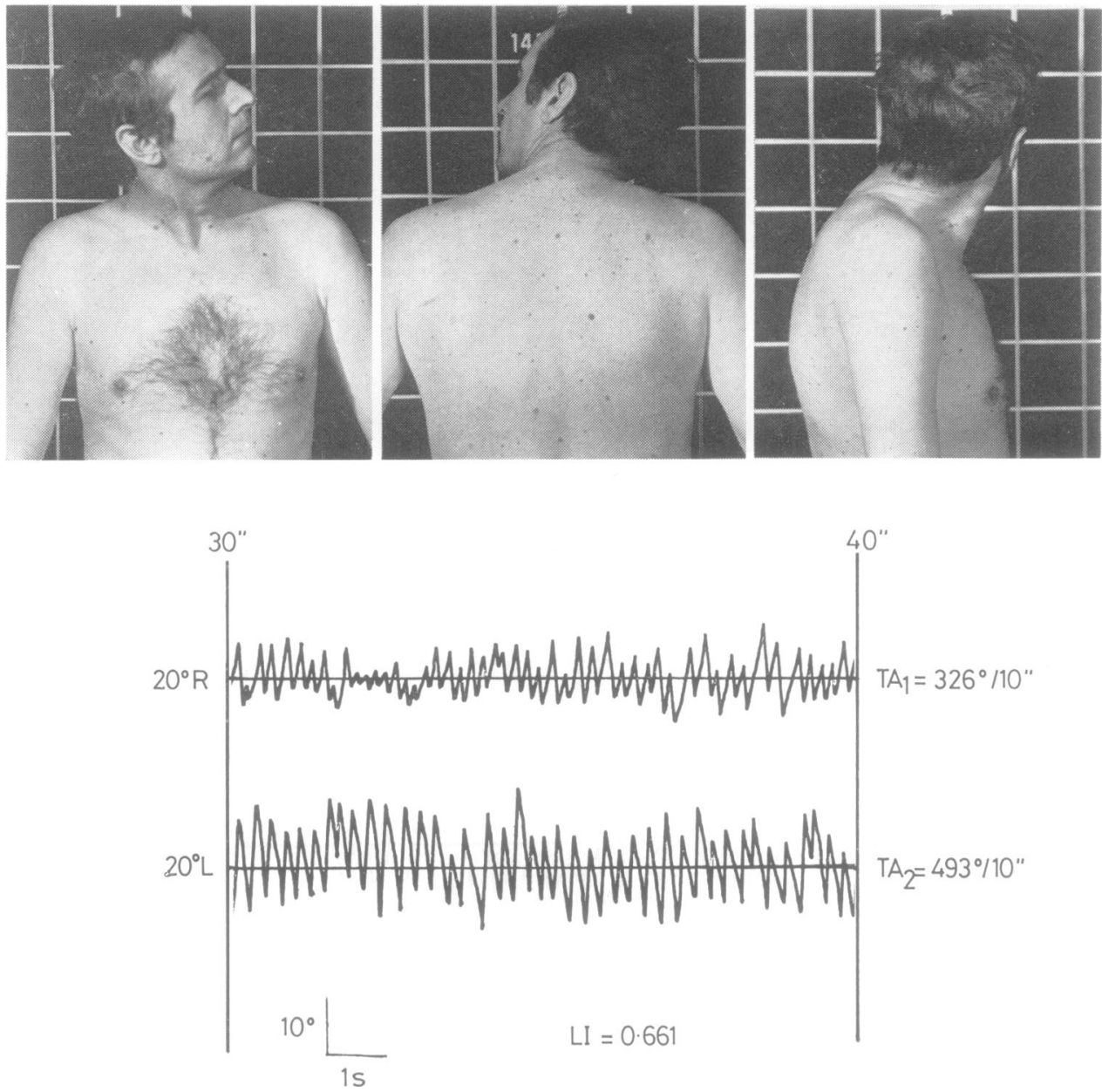

Fig 3 Nystagmus pattern in a man suffering from torticollis with rotation of the head to the left.

The total amplitude of the caloric nystagmus with slow phases to the left $\left(\mathrm{TA}_{2}\right)$ predominates.

"whirling fit". ${ }^{26}$ The rotational character of the seizure is its prominent feature and the direction of the turning is in most dogs constant. The "left-sided fit" begins with the turning of the head to the left, followed by circling to the left and then the animal falls on its left side and generalised convulsions appear. ${ }^{27}$ During the interictal period, the "leftsided" dog walks in the cage predominantly in circles to the left. This stereotyped repetitive walking in circles of constant direction was described mainly in laboratory and zoo-reared foxes, dingos and wolves. ${ }^{28}$ It was concluded that both the laterality of seizures and the motor stereotypy was based on a predominant asymmetry of postural functions. ${ }^{29}$

Data is available to suggest that in healthy man also exists a postural asymmetry (laterality) of rotational motor stereotypes. A predisposition for turning to the left prevails. In radiographs of the occipital condyles and $\mathrm{C} 1$ vertebrae, Jirout ${ }^{30}$ found a symmetrical position in $30 \%$ of healthy subjects, but in $57 \%$ the condyles were deviated to the right (that is the head rotated to the left), and in 13\% the condyles were deviated to the left. In EMG studies there is a prevalence of activity of the left-sided semispinalis neck muscles (prime-movers of ipsilateral rotation of the head) in right-handed standing subjects. $^{31}$ Rotational movements in basic motor patterns of the axis of the body are predominantly associated with tilting of the body to the other side, so the predominance of left-sided rotation is in 
accord with the stabilographic observations. ${ }^{32}$ The authors showed in healthy subjects a tendency to tilt to the right, while other authors ${ }^{33}$ showed that lateral oscillations of the vertical axis tended to be to the right side. In walking and stepping tests most right-handed people deviate to the right. ${ }^{34}$

Asymmetry of postural functions in healthy subjects also has been shown in caloric, rotatory and optokinetic nystagmus (physiologic directional preponderance of nystagmus). The mean frequency of optokinetic nystagmus to the left is higher (3.57/s) than to the right $(3 \cdot 17 / \mathrm{s}) .{ }^{35}$ In right-handed subjects, Jongkees $^{36}$ showed a directional preponderance of postrotational nystagmus to the left; Cigánek ${ }^{37}$ found a directional preponderance of optokinetic nystagmus to the left. Caloric nystagmus to the left has been found to be larger and of longer duration ${ }^{38}$ than nystagmus to the right and the velocity of its slow phase greater. ${ }^{36}$

Most subjects with spasmodic and also with congenital torticollis rotate to the left (table 3 ).

Table 3 Direction of rotational component of torticollis

\begin{tabular}{llcc}
\hline Authors & $\begin{array}{l}\text { Type of } \\
\text { torticollis }\end{array}$ & $\begin{array}{l}\text { To the } \\
\text { left }\end{array}$ & $\begin{array}{l}\text { To the } \\
\text { right }\end{array}$ \\
\hline Arseni and Sandor, 196039 & spasmodic & 28 & 13 \\
Sorensen and Hamby, 196540 & spasmodic & 43 & 28 \\
Hamby and Schiffer, 196941 & spasmodic & 27 & 23 \\
MacDonald, 196942 & congenital & 68 & 34 \\
Ling and Low, 197243 & congenital & 105 & 45 \\
Bösch, 197244 & congenital & 229 & 158 \\
Stejskal and Tománek & spasmodic & 71 & 57 \\
\hline
\end{tabular}

In our study, the direction of the rotational component of torticollis was found to parallel the rotational postural laterality. The dyskinesia may be regarded as due to pathological release of a preexisting postural laterality.

The cooperation of the Data Processing Department of the UVN Hospital, Prague, is gratefully acknowledged.

\section{References}

${ }^{1}$ Hassler R, Dieckmann G. Die stereotaktische Behandlung des Torticollis aufgrund tierexperimenteller Erfahrungen über die richtungsbestimmten Bewegungen. Nervenarzt 1970;41:473-87.

2 Stejskal L. Therapeutic results in axial hyperkinsias including torticollis. The effect of the plane of deviation. J Neurol Sci 1975;25:481-90.

${ }^{3}$ Richter $H$. Beitrāge zu Klinik und pathologische Anatomie der extrapyramidalen Bewegungsstörungen. Arch Psychiatr Nervenkr 1923;67:226-94.

4 Cassirer R. Halsmuskelkrampf und Torsionspasmus. Klin Wochenschr 1924;1:53-6.
${ }^{5}$ Wimmer A. Le spasme de torsion. Rev Neurol (Paris) $1929 ; 36: 904-15$.

${ }^{6}$ Marinesco G, Nicolesco M. Un cas anatomo-clinique de dystonie contorsive spasmodique avec lésion de striatum et des centres sous-thalamiques. Rev Neurol (Paris) 1929;36:973-80.

'Davison, C, Goodhart SP. Dystonia musculorum deformans: clinico-pathological study. Arch Neurol 1933;29:1108-24.

${ }^{8}$ Schmitt W, Scholz W. Klinischer und pathologischanatomischer Beitrag zur Torsiondystonie. Dtsch Z Nervenhk 1933;126:53-79.

${ }^{9}$ Vogt C, Vogt O. Morphologische Gestaltungen unter normalen und pathogenen Bedingungen. $J$ Psychol Neurol (Leipzig) 1941-42;50:382-4.

${ }^{10}$ Hassler R, Dieckmann G. Stereotactic treatment of different kinds of spasmodic torticollis. Conf Neurol 1970;32:135-43.

${ }^{11}$ Hassin GB, Poncher HG. Dystonia musculorum deformans: clinico-pathological report of a case. Am J Dis Child 1939;57:105-15.

${ }^{12}$ DeLange $C$. Dystonia musculorum progressiva (Torsiondystonie). Ann Paediat (Basel) 1945;164:169-81.

${ }^{13}$ Tarlov E. On the problem of the pathology of spasmodic torticollis in man. $J$ Neurol Neurosurg Psychiatry 1970;33:457-63.

${ }^{14}$ Zeman W, Dyken P. Dystonia musculorum deformans. Clinical genetic and pathoanatomical studies. Psychiatr Neurol Neurosurg 1967;70:77-121.

${ }^{15}$ Rose M. Die morphologische Grundlage der Torsiondystonie. Arch Nauk Biol Tow (Warsz) 1937;6:1-19.

${ }^{16}$ Foerster O. Mobile spasm of the neck muscles and its pathological basis. J Comp Neurol 1933;58:725-35.

${ }^{17}$ Alpers BJ, Drayer CS. The organic background of some cases of spasmodic torticollis. Am J Med Sci 1933;193:378-84.

${ }^{18}$ Grinker RR, Walker AE. The pathology of spasmodic torticollis with a note on respiratory failure from anaesthesia in chronic encephalitis. $J$ Nerv Ment Dis $1933 ; 78: 630-7$.

${ }^{19}$ Alexander L. The fundamental types of histopathologic changes encountered in cases of athetosis and paralysis agitans. Res Publ Assoc Res Nerv Ment Dis $1942 ; 21: 334-493$.

${ }^{20}$ Solcher $\mathrm{H}$. Über einen Fall von überstandener fötaler Kohlenoxydvergiftung. J Hirnforsch (Berlin) 1943; 3:49-55.

${ }^{21}$ Roessmaan U. Schwartz JF. Familial striatal degeneration. Arch Neurol 1969;29:314-8.

22 Podivinský F. Torticolis. In: Vinken PJ and Bruyn GW, eds. Diseases of the Basal Ganglia. Amsterdam: North Holland Publ Comp, 1968:567-603.

${ }^{23}$ Kimura D. Cerebral dominance and the perception of verbal stimuli. Can J Psychol 1964;15:166-71.

${ }^{24}$ Fitzgerald G, Hallpike CS. Studies on human vestibular function: I. Observations on the directional preponderance ("Nystagmusbereitschaft") of caloric nystagmus, resulting from cerebral lesions. Brain 1942;65:115-37.

${ }^{25}$ Maier NRF. Frustration. New York: 1949. Quoted by Barnett SA. "Displacement" behaviour and "psycho somatic" disorder. Lancet 1955;1203-8. 
${ }^{26}$ Thompson WR, Melzack R, Scott TH. "Whirling" behavior in dogs as related to early experience. Science 1956;123:939.

${ }^{27}$ Martínek Z, Horák F. Problem of lateral dominance in epileptic seizure in dogs. Physiol Bohemoslov 1971; 20:388.

${ }^{28}$ Holzapfel $M$. Über Bewegungsstereotypien bei gehaltenen Säugern. Fortschr Tierphysiol Tierernaehr 1938;2:46-72.

${ }^{29}$ Martínek Z, Dahme E. Spontanepilepsie bei Hunden: Langzeituntersuchungen an einer Gruppe genetisch verwandter Tiere. Zentralbl Veterinaermed $(A)$ 1977; 24:253-71.

${ }^{30}$ Jirout J. Zur Statik der Kopfgelenke. Man Med 1978; 16:1-5.

${ }^{31}$ Süssová J. The influence of the laterality on the axial muscles. Dissertation, Charles University, Prague: 1972.

${ }^{32}$ Niederlandová Z, Litvinenková V. Stabilographic findings in strabismus. Agressologie 1973;14D:33-6.

33 Cernáček J, Jágr J. The influence of visual factors on the lateral deviation of the body axis. Act Nerv Super (Praha) 1975;17:55-62.

34 Milojevic B, Watson JL. Vestibular asymmetries in right- and left-handed people. Acta Otolaryngol (Stock) 1965;60:322-30.
${ }^{35}$ Cords R. Optisch-motorisches Feld und optischmotorische Bahn. Albrecht von Graefes Arch Klin Exp Ophthalmol 1926:117:58-75.

36 Jongkees LBW. Über die Untersuchungsmethoden des Gleichgewichtsorgans. Basel/New York: Karger, 1953.

${ }^{37}$ Cigánek L. On the physiologic asymmetry of the optokinetic nystagmus. In: Cernáček J, ed. Problems of Neurophthalmology. Bratislava: SAV, 1957:152-64.

${ }^{38}$ Aschan G. Response to rotary stimuli in fighter pilots. Acta Otolaryngol (Stock) 1954;116:3-9.

${ }^{39}$ Arseni C, Sandor G. Klinisch-statistische Analyse von 50 operierten Fällen von Torticollis spasticus. Zentralbl Neurochir 1960;20:91-7.

${ }^{40}$ Sorensen F, Hamby WB. Spasmodic torticollis. JAMA 1965;194:706-8.

${ }^{41}$ Hamby WB, Schiffer S. Spasmodic torticollis: results after cervical rhizotomy in 50 cases. $J$ Neurosurg 1969;31:323-6.

42 MacDonald D. Sternomastoid tumor and muscular torticollis. J Bone Joint Surg (Br) 1969;51:432-40.

${ }^{43}$ Ling CM, Low YS. Sternomastoid tumor and muscular torticollis. Clin Orthop 1972;86:144-50.

${ }^{44}$ Bösch J. Operative treatment of wry-neck. A follow-up study over a period of 27 years. Wien Klin Wochenschr 1972;84:688-90. 